\title{
Studies of E. coli and Coliform Bacteria Contamination in Mussels (Geukensia demissa) Collected from Guion Creek and Its Correlation to Water Flow Rate
}

\author{
Pretima G. Persad and Anna K. Yeung-Cheung* \\ Department of Biology \\ Manhattanville College \\ Purchase, New York 10577 USA
}

Received: May 15, 2007 Accepted: December 15, 2007

\begin{abstract}
Ribbed mussels (Geukensia demissa) were collected from a highly contaminated Guion Creek, Mamaroneck Harbor, NY and were compared with Harbor Island Park and Shore Acres Beach, for amounts of bacteria. Mussels were also collected from a pristine beach, Read Sanctuary, Rye. The water flow rate was measured at all sites. The results showed that the amount of $E$. coli and coliform bacteria recovered from mussels were significantly higher in Guion Creek and its water flow rate was significantly lower when compared to three other sites. On the contrary, the highest water flow rate and lowest amounts of bacteria were recovered from mussels collected at Read Sanctuary. A negative correlation of water flow rate with amounts of $E$. coli and coliform recovered from mussels at all sites was found. Results suggested that a slow water flow rate in Guion Creek might be one of the contributing factors to the high bacterial loads.
\end{abstract}

\section{INTRODUCTION}

Westchester County in New York is a densely populated area; the housing developments and human activities in the recent decades have caused the deterioration in the quality of streams and wetlands. Guion Creek, a freshwater estuary located in Mamaroneck, NY was found to have high levels of Escherichia coli (E. coli) and coliform bacteria from water and sediment in our previous studies (Yeung-Cheung et al. unpublished data). Water from Guion Creek flows into the Mamaroneck Harbor where Harbor Island Park and Shore Acres Beach are located. These two beaches have been frequently closed each summer especially after heavy rainfall in order to avoid high amounts of bacterial contamination [1]. The presence of E. coli and fecal coliform bacteria in water are frequently used as contamination indicators and are related to the increased risk of gastrointestinal symptoms [2]. US

* Corresponding Author. Email Address:

cheunga@mville.edu
Federal standards suggest the use of $E$. coli as an indicator for fresh recreational waters and enterococci testing for both fresh and marine recreational waters [3].

The habitat at Guion Creek is different when compared to the other two beaches because of the geographic nature of the narrow creek. A large storm drain opening also empties directly into Guion Creek. South Barry Bridge is located west of our collection site, approximately 500 feet down from the beginning of the creek. This bridge has created a big obstruction for fresh water to come into the narrow creek. The introduction of man-made concrete structures and stones to hold the bridge up has limited about 22 feet of space where fresh water would be able to enter the creek. The construction of this bridge may pose an effect on slowing the water flow rate into the creek and thus affecting the concentration of bacterial loads in the water. Mallin et al. [4] indicated that an increase in fecal coliform bacteria in the watershed was correlated with land development. Natural flushing by tides brings in fresh seawater from a larger source. However, some areas on the Long 


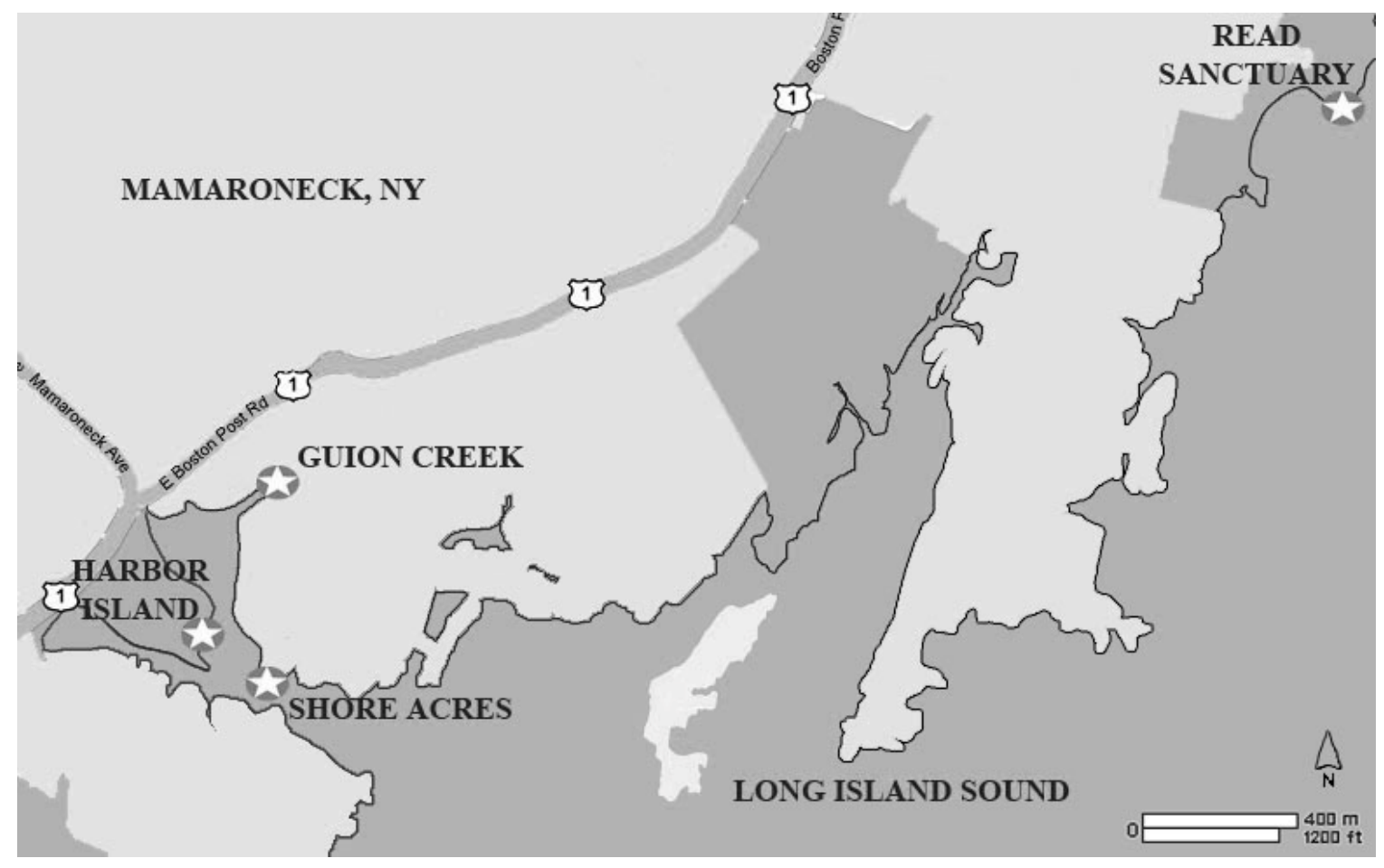

Figure 1. The map of Mamaroneck Harbor and Read Sanctuary with 4 collection sites, stars represent sites for mussel collection.

Island Sound, such as the inlet of Mamaroneck Harbor is harder to flush out. The inability for water to flush out of these estuaries create stagnant pools and are subject to bacterial contamination.

Many physical factors can possibly contribute to bacterial contamination in water such as sewage contamination [5], heavy rainfall [6], fecal material from humans and warm-blooded animals [7] and seagulls and geese $[8,9]$. Nearby boat dock points and gasoline stations may also contribute to high densities of $E$. coli in water [10]. Byrne et al. [11] recently indicated that reduced water flow rates might increase the deposition of bacteria in water columns. Here, we would like to investigate the effect of the water flow rate in Guion Creek relative to the amount of bacteria recovered in the mussels.

Our study focused on recovering bacteria from ribbed mussels (G. demissa) in these areas. Mussels are well-known filter feeders [12] and serve as good bioindicators for testing bacteria in water. The ribbed mussel proved to be one of the most effective experimental models as they have been seen to show an unusual tolerance to dehydration, variation in salinity and thermal stress [13]. Mussels have also been shown to be particularly important as bioindicators of chemical pollutants in the environment $[14,15]$. Our goal is to use the ribbed mussel as a model and to study the relationship of water flow rate relative to the amounts of bacteria recovered from the mussels at all sites.

\section{MATERIALS AND METHODS}

\section{a. Field-Site Description}

Three ribbed mussels (G. demissa) were collected each week from Harbor Island Park, Guion Creek, a small, mostly stagnant creek; Shore Acres Beach, a private beach adjacent to Harbor Island Park and Read Sanctuary, a private and pristine beach in Rye (Figure1).

\section{b. Mussel Collection}

Collection was done during low tide from June 2006-October 2006 once per 


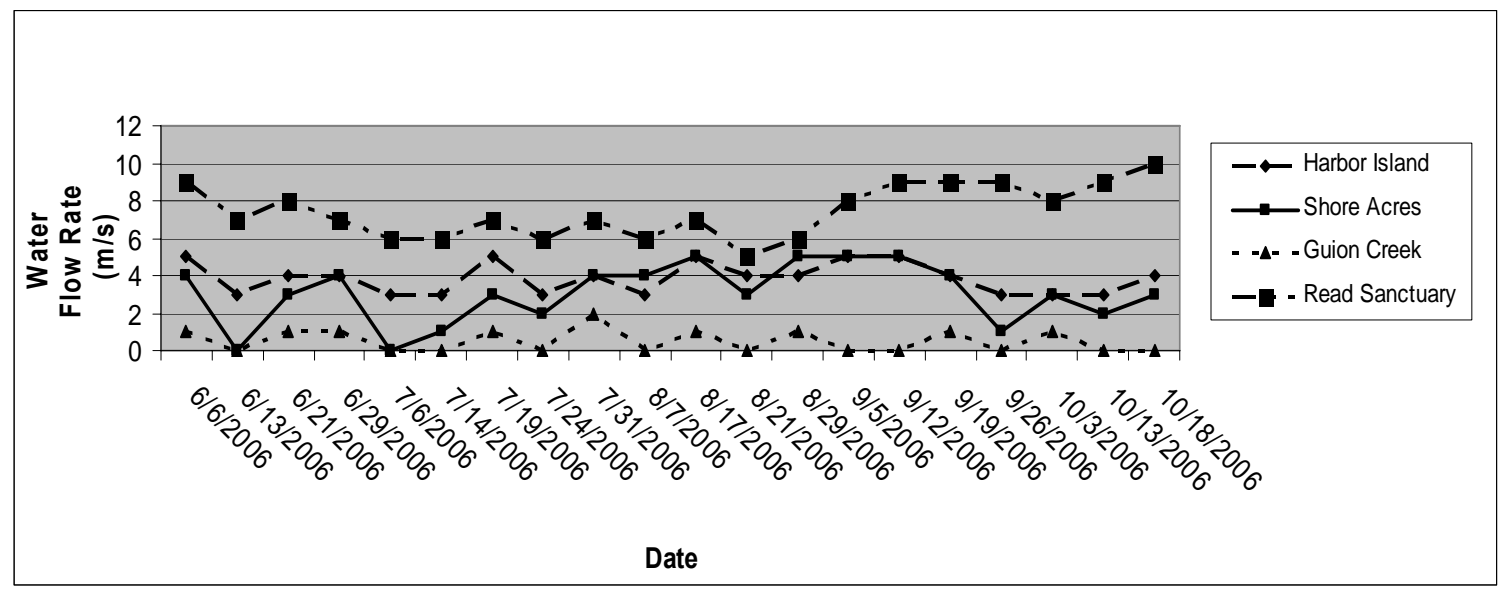

Figure 2. Water flow rate $(\mathrm{m} / \mathrm{s})$ measured at 4 sites at low tide from June to October 2006.

week. The mussels were removed and placed into individual clean containers. Water from sites where the mussels were collected was also placed in these containers. All mussels were taken back to the laboratory for immediate processing. Rainfall before or on the date of collection was recorded, water temperature and water flow rate were also recorded. The water flow rate was measured using a flow meter $\left(\right.$ Geopacks ${ }^{\circledR}$, UK) by placing it into the water near where the mussels were collected and the flow rate $(\mathrm{m} / \mathrm{s})$ was recorded.

\section{c. Mussel Processing}

The length of each mussel was measured and recorded. The shells were removed and the meat of the mussel, minus the adductor muscle, was weighed in grams. The meat from each mussel was added to an extraction buffer at a 1:10 dilution and processed according to methods outlined in Yeung-Cheung \& Melendez [16]. The mussel and buffer were ground in an autoclave sterilized glass test tube in an ice bath to prevent external heat from being generated. After grinding was completed, 1 $\mathrm{ml}$ of the homogenate was evenly placed on a $3 \mathrm{M}^{\circledR}$ Petrifilm $^{\mathrm{TM}}$ (3M Company, MN). The films were then incubated for about 24 hours at $37^{\circ} \mathrm{C}$. After incubation was completed, the films were interpreted according to the $3 \mathrm{M}^{\circledR}$ Petrifilm ${ }^{\mathrm{TM}}$ color guide and resulting bacterial colonies were enumerated as colony forming units (CFU).

\section{d. Statistical Analysis}

A one-way ANOVA with a Tukey Post-Hoc test for means was employed using SPSS for Windows in order to study the comparison of the lengths and weights of mussels from all 4 sites; the same statistical analysis was used in determining the comparisons of the amounts of $E$. coli and coliform bacteria recovered from each mussel from all sites. A two-tailed Pearson correlation was used in determining the correlation of water flow rate with $E$. coli and coliform bacteria found in mussels. The same correlation method was also used in determining the effect of rainfall on the amount of bacteria recovered from the mussels.

\section{RESULTS}

\section{a. Properties of Water}

At all sites, water temperature ranged from $16-28^{\circ} \mathrm{C}$ between June and October 2006 (data not shown). Water temperature decreased steadily from June to October. The water temperature was about the same at Harbor Island Park and Shore Acres Beach, varying only by 1 or 2 degrees. Rainfall occurred on 12 out of 20 days before collection, with 3 days reaching over 0.5 inches and 9 days reaching over 0.25 inches of rainfall. When taken at low tide, the water flow at Read Sanctuary was the fastest, averaging $7.45 \mathrm{~m} / \mathrm{s}$. The average water flow was similar at Harbor 


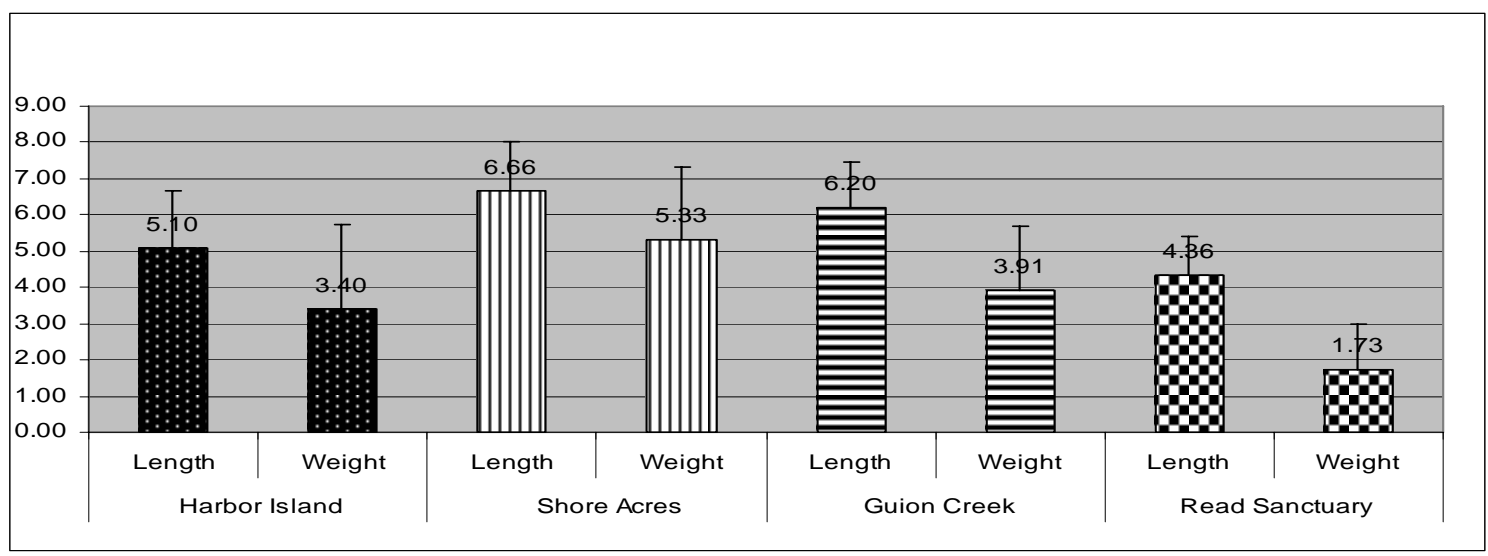

Figure 3. The mean length (cm) and weight (grams) (+SE) of mussels collected from 4 sites from June to October 2006.

Island Beach $(3.85 \mathrm{~m} / \mathrm{s})$ and Shore Acres Beach $(3.05 \mathrm{~m} / \mathrm{s})$. Guion Creek had the slowest water flow rate, averaging $0.5 \mathrm{~m} / \mathrm{s}$, with 11 collection days exhibited a flow rate of $0 \mathrm{~m} / \mathrm{s}$ (Figure 2) and was significantly lower than the other 3 sites $(p<0.05)$.

\section{b. Properties of Mussels}

The mussels collected from Shore Acres Beach were larger in size and weight than the mussels collected from the 3 other sites, as they averaged $6.66 \mathrm{~cm}$ in length and 5.33 grams. Mussels collected from Read Sanctuary were the smallest and averaged $4.36 \mathrm{~cm}$ and 1.73 grams (Figure 3). When the lengths and weights of mussels from the 4 sites were compared, the mussels collected from Read Sanctuary were significantly smaller than the mussels collected from the other 3 sites $(p<0.05)$.

c. Amount of E. coli and Coliform Recovered from Mussels

Higher amounts of $E$. coli and coliform bacteria were present in mussels at Guion Creek when compared to the other 3 sites $(p<0.05)$. An average amount of 395 CFU of E. coli/g of meat was found in mussels collected from Guion Creek. The average amounts of $E$. coli recovered from Harbor Island Park (251 CFU/g of meat) and Shore Acres Beach (243 CFU/g of meat) were similar. Mussels collected from Read Sanctuary had the lowest amounts of bacteria (138 CFU/g of meat) (Figure 4). Regarding the recovery of coliform bacteria, mussels collected from Guion Creek also had the highest amounts, averaging 853 CFU/g of meat. There was an average of 635 CFU of coliform/g of meat collected from mussels at Harbor Island Beach and $612 \mathrm{CFU}$ of coliform/g of meat recovered from mussels at Shore Acres Beach. Read Sanctuary had the lowest with an average of $355 \mathrm{CFU}$ of coliform $/ \mathrm{g}$ of meat recovered from its mussels (Figure 5). A Pearson correlation analysis indicated a negative correlation of water flow rate with the amount of $E$. coli $(p<0.05 ; r=-0.64)$ and coliform bacteria $(p<0.05 ; r=-0.76)$ at all sites. The relative correlation of water flow rate with the amount of $E$. coli and coliform bacteria recovered from mussels is shown in Figure 6 and Figure 7 respectively. However, there was no conclusive correlation with the effect of rainfall on the amounts of bacteria recovered from mussels at all sites.

\section{DISCUSSION}

In our studies, we demonstrated that water flow rate had a direct correlation with the bacterial loads recovered from mussel tissue. Higher amounts of $E$. coli and coliform bacteria were found in mussels from Guion Creek along with the slowest water flow rate when compared to the other 3 sites. Our previous study revealed a high amount of bacteria found in water and sediment from Guion Creek. Here, we also found similarities in the higher levels of bacteria recovered in mussels from the creek. However, the water flow rate was 


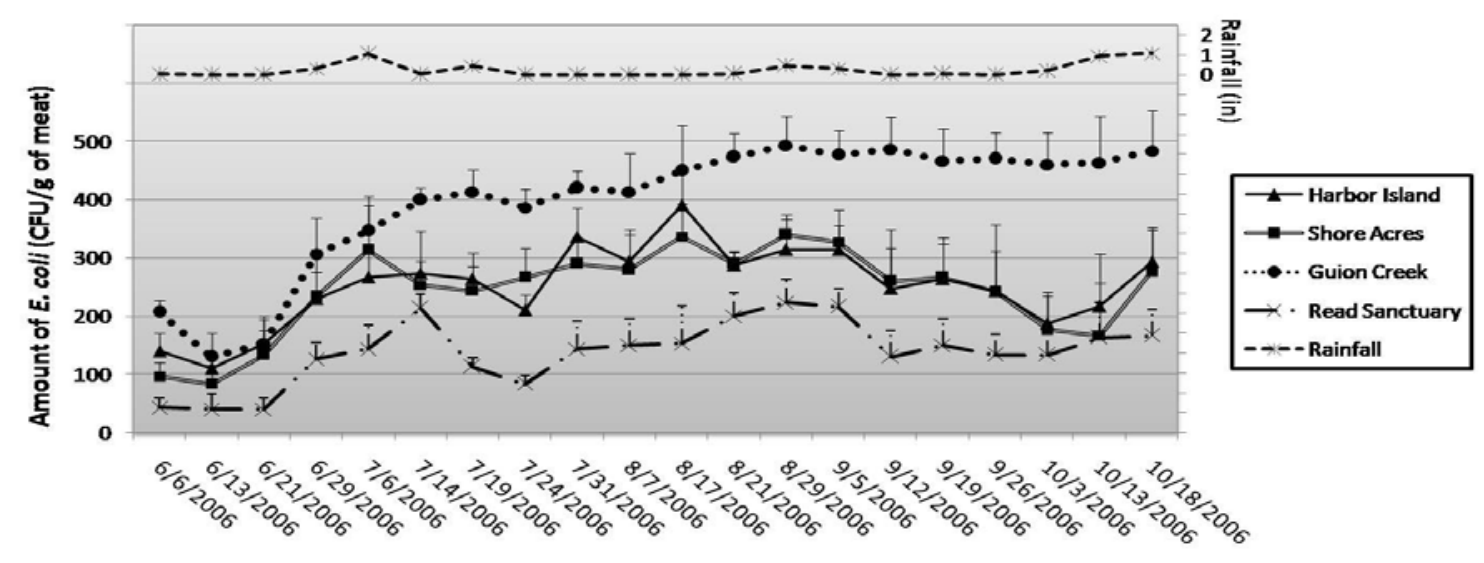

Date

Figure 4. The average amount of $E$. coli (+SE) recovered from mussels at 4 sites from June to October 2006 along with the amount of rainfall.

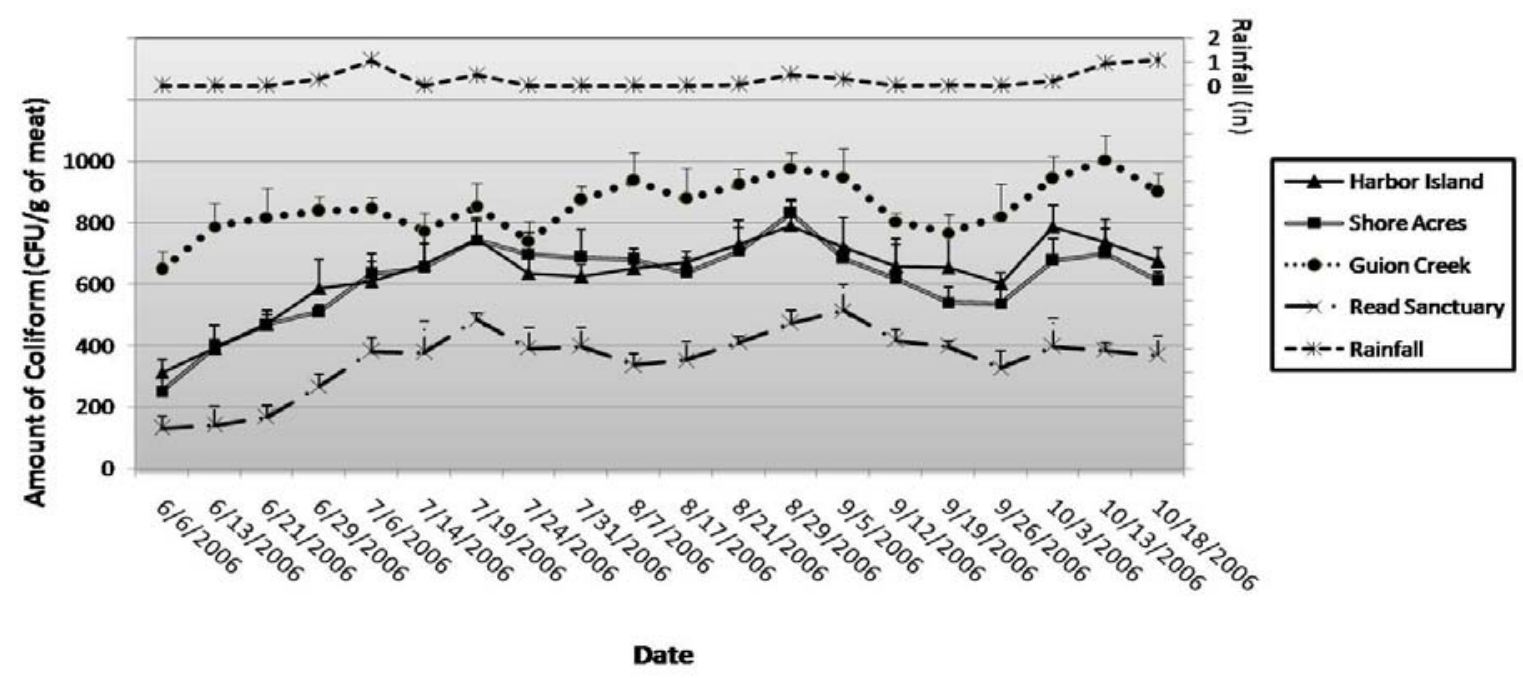

Figure 5. The average amount of coliform (+SE) recovered from mussels at 4 sites from June to October 2006 along with the amount of rainfall.

found to be significantly slower in Guion Creek. This may be due to its geographic nature of being a narrow creek along with the fact that South Barry Bridge can possibly limit the capacities for water flow. Fresh water from natural tidal flushing may not be able to properly reach the creek and stagnant pools contaminated with bacteria may be created. Tidal flushing is an important factor affecting bacterial levels in water. Previous studies have shown that large quantities of industrial and sewage effluents might alter an ecosystem of a watershed and its bacterial concentrations.
A system of wind-driven mixing and tidal flushing keep the water well aerated, and thus reduce the pollution [17]. Studies have also shown reduced water flow rates promoting bacterial growth and concentrations on marine sponges [18]. In comparison to the other sites, another field observation revealed an abundance of birds to be in the vicinity of Guion Creek; previous studies have indicated that fecal material from birds and geese could contribute to high bacterial contamination in surrounding waters [9]. In addition, the water from the storm drain that empties directly into the 


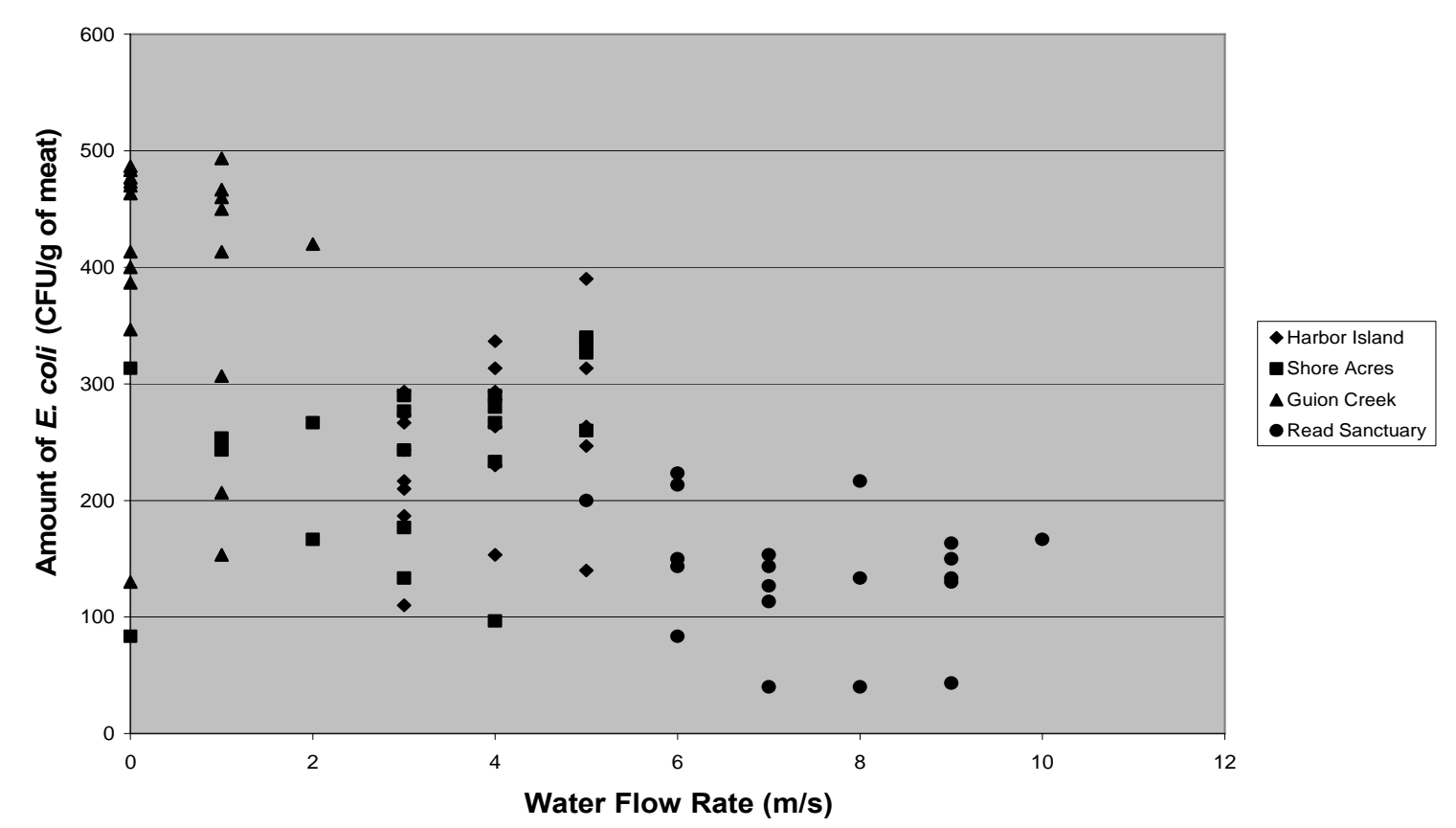

Figure 6. The correlation of water flow rate with the amount of $E$. coli bacteria at all sites.

Guion Creek may act as another potential source for water contamination. These waters are a result of the collection of many smaller storm drains from the streets above the creek and the surrounding areas in Mamaroneck. Storm water runoff is known for containing high levels of bacteria and is an important source of contamination impacting on recreational and drinking waters [19].

A steady increase in the amounts of E. coli and coliform bacteria at each site from June to July was seen. This may be due to the increased growth of bacteria in higher temperatures in the month of July. In addition, a similar amount of $E$. coli and coliform bacteria were recovered from mussels in Harbor Island Park and Shore Acres Beach. These 2 beaches are geographically located adjacent to each other and it is not surprising that the water flow rates and water temperatures from these 2 beaches are similar. Read Sanctuary had the lowest amount of bacteria recovered from mussels along with the highest water flow rates when compared to the other 3 sites. This may be due to the fact that Read Sanctuary is a direct beach located further east on the Long Island
Sound, instead of being located in an inlet as the other 3 sites are, and thus, Read Sanctuary may receive better flushing from the tides. These results correlated with a previous study showing significantly lower amounts of $E$. coli and coliform bacteria recovered from water and clams in Read Sanctuary as compared to the outside of the Gunderboom $^{\circledR}$ at Harbor Island Park [16]. Although the lengths and weights of the mussels from Read Sanctuary were lower when compared to the other sites, this may just be due to the natural habitat of these mussels. Sherwood \& Petraitis [20] compared $G$. demissa with another species of mussel and found that the size of mussels were not significant with respect to their species, state and microhabitat.

We collected half of the mussels the day after rainfall and we observed a higher amount of $E$. coli and coliform bacteria recovered from mussels on some of these days. However, no conclusive correlation was obtained from rainfall data with the amount of bacteria recovered from mussels at each site. Brock et al. [21] supported the restriction of harvesting mussels on days after heavy rainfall due to higher bacterial levels found in these mussels. However a 


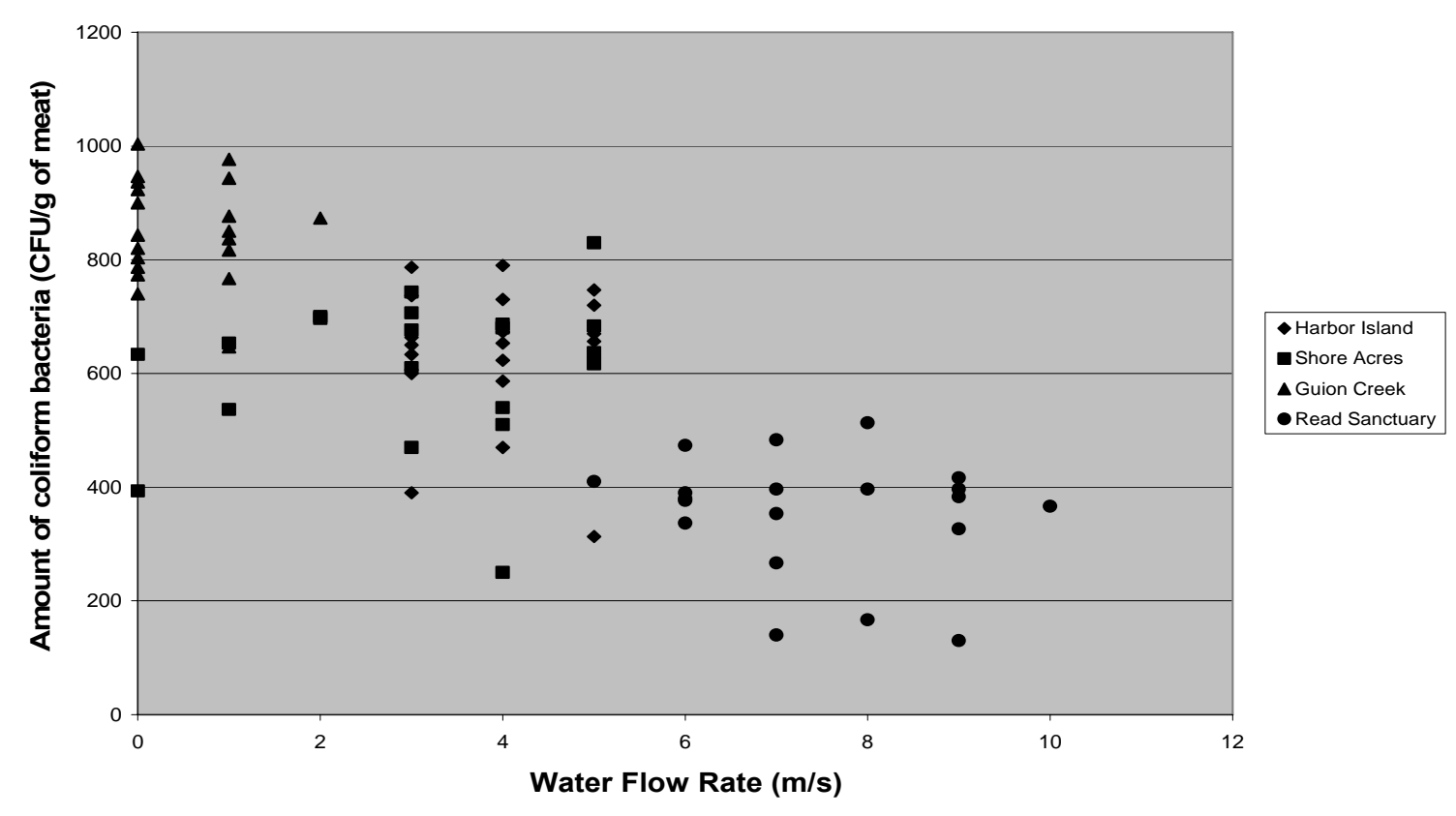

Figure 7. The correlation of water flow rate with the amount of coliform bacteria at all sites.

recent study from Whitman et al. [22] indicated the effect of rainfall on the amount of bacteria recovered from water and sediment to be temporary, as these levels quickly returned to their original pre-rain conditions. No significant relationship between rainfall and increased amounts of bacteria was found in another study at the Lake Superior Beaches [23].

Mussels are widely used as bioindicators in the marine environment not only because of their abundance, but also because of their success in previous studies $[24,25]$. In our study, the ribbed mussel proved to be a suitable bioindicator to use in studying the environment within Mamaroneck Harbor and concluded that mussels recovered from Guion Greek had the highest amounts of $E$. coli and coliform bacteria when compared to the downstream area where the 2 recreational beaches are located. The slow water flow rate of Guion Creek was correlated with the high amount of bacteria recovered from the mussels. Here, we may not be able to rule out all factors causing the water contamination in Guion Creek. However, we suspect the geographic nature of a narrow creek located in the inlets of Long Island Sound and the man-made bridge obstruction of the fresh water causing the slow water flow rate might be one of the contributing factors to the high level of bacterial contamination.

\section{CONCLUSIONS}

- A higher amount of bacteria and slower water flow rates were significantly found in mussels from Guion Creek when compared to the downstream areas of the 2 recreational beaches.

- A negative correlation of water flow rate with the amount of bacteria was revealed at all sites.

- The bacterial contamination of Guion Creek may be due to the narrow geographic nature of the creek and the man-made bridge causing the slow water flow rate.

- There was no conclusive correlation of rainfall effect on the amount of bacteria recovered at all sites.

\section{ACKNOWLEDGEMENTS}

We would like to thank Mayor Philip Trifiletti, Nancy Todd, Wendy McFarlane, Peter 
Hallock and the staff of Read Sanctuary for their input in this project.

\section{REFERENCES:}

1. US EPA, BEACON. (2006) Beach advisory and closing on-line notification. Beach data for Harbor Island Park and Shore Acres Beach [online]. http://oaspub.epa.gov/beacon/beacon_h istorical_data.main?p_beach_id $=26642$ \&p_county_fips $=119 \& p \_s t a t e \_f i p s=36$ [accessed May 2007] http://oaspub.epa.gov/beacon/beacon_h istorical_data. main?p_beach_id $=2665 \overline{5}$ $\& p \_c o u n t y \_f i p s=119 \& p \_s t a t e \_$fips $=36$ [accessed May 2007]

2. Pruss, A. (1998) Review of epidemiological studies on health effects from exposure to recreational water. Int. J. Epidemiol., 27, p.1-9.

3. US EPA. (1986) Ambient water quality criteria for bacteria. Office of water regulations and standards; criteria and standard division. Washington, DC, (EPA440/5-84-002).

4. Mallin, M.A., Williams, K.E., Esham, E.C., and Lowe, R.P. (2000) Effect of human development on bacteriological water quality in costal watersheds. Ecol. Appl., 10 (4), p.1047-1056.

5. Boehm, A.B., Fuhrman, J.A., Mrse, R.D., and Grant, S.B. (2003) Tiered approach for identification of a human fecal pollution source at a recreational beach: case study at Avalon Bay, Catalina Island, California. Environ. Sci. Technol., 37 (4), p.673-680.

6. Crowther, J., Kay, D., and Wyer, M.D. (2001) Relationships between microbial water quality and environmental conditions in coastal recreational waters: the Fylde Coast, UK. Water Res., 35 (17), p.4029-4038.

7. Gerba, C.P. (2000) Assessment of enteric pathogen shedding by bathers during recreational activity and its impact on water quality. Quan. Microbiol., 2, p.55-68.

8. Levesque, B., Brousseau, P., Simard, P., Dewailly, E., Meisels, M., Ramsay, D., and Joly, J., (1993) Impact of the Ring-Billed Gull (Larus delawarensis) on the microbiological quality of recreational water. Appl. Environ. Microbiol., 59 (4) p.1228-1230.
9. Alderisio, K.A., and DeLuca, N. (1999) Seasonal enumeration of fecal coliform bacteria from the feces of ring-billed gulls (Larus delawarensis) and Canada geese (Branta canadensis). Appl. Environ. Microbiol., 65(12) p.5628-5630.

10. An, Y.J., Kampbell, D.H. and Breidenbach, G.P. (2002) Escherichia coli and total coliforms in water and sediments at lake marinas. Environ. Pollut., 120, p.771-778.

11. Bryne, J., Kienzle, S., Johnson, D., Duke, G., Gannon, V., Selinger, B., and Thomas, J. (2006) Current and future water issues in the Oldman River Basin of Alberta, Canada. Water Sci. Technol., 53(10), p.327-34.

12. Silverman, H., Achberger, E.C., Lynn, J.W., and Dietz, T.H. (1995) Filtration and utilization of laboratory-cultured bacteria by Dreissena polymorpha, Corbicula fluminea, and Carunculina texasensis. Biol. Bull., 189, p.308-319.

13. Lent, C. M. (1969) Adaptations of the ribbed mussel, Modiolus demissus (Dillwyn), to the intertidal habitat. $A m$. Zool., 9(2), p.283-292.

14. O'Connor, T. P. (2002) National distribution of chemical concentrations in mussels and oysters in the USA. Mar. Environ. Res., 53(2), p.117-143.

15. Hellou, J., and Law, R.J. (2003) Stress on stress response of wild mussels, Mytilus edulis and Mytilus trossulus, as an indicator of ecosystem health. Environ. Pollut., 126(3), p.407-416.

16. Yeung-Cheung, A., and Melendez, N.J. (2007) The efficacy of the Gunderboom ${ }^{\circledR}$ in Mamaroneck Harbor on the reduction of $E$. coli and coliform bacteria from water and soft-shelled clams (Mya arenaria) J. Environ. Sci. Health Part A., 42, p.143-148.

17. Verlecar, X.N., Desai, S.R., Sarkar, A., and Dalal, S.G. (2006) Biological indicators in relation to coastal pollution along Karnataka coast, India. Water Res., 40(17), p.3304-3312.

18. Hummel, H., Sepers, A.B.J., de Wolf, L., and Melissen, F.W. (1988) Bacterial growth on the marine sponge Halichondria panicea induced by reduced waterflow rate. Mar. Ecol. Prog. Ser., 42(2), p.195-198.

19. Marsalek J., and Rochfort, Q. (2004) Urban wet-weather flows: sources of 
fecal contamination impacting on recreational waters and threatening drinking-water sources. J. Toxicol. Environ. Health, 67(20), p.1765-1777.

20. Sherwood, R.M., and Petraitis, P.S. (1998) Mortality differences of two intertidal mussels, Mytilus edulis L. and Geukensia demissa (Dillwyn), in a New Jersey salt marsh. J. Exp. Mar. Bio. Ecol., 231(2), p.255-265.

21. Brock, R.L., Galbraith, G.R. and Benseman, B.A. (1985) Relationships of rainfall, river flow, and salinity to faecal coliform levels in a mussel fishery. $N$. $Z$. J. Mar. Freshwat. Res.,19, p.485-494.

22. Whitman, R. L., Nevers, M.B., and Byappanahalli, M.N. (2006) Examination of the watershed-wide distribution of Escherichia coli along Southern Lake Michigan: An integrated approach. Appl.
Environ. Microbiol., 72(11), p.73017310.

23. Sampson, R.W., Swiatnicki, S.A., McDermott, C.M., and Kleinheinz G.T. (2006) The effects of rainfall on Escherichia coli and total coliform levels at 15 Lake Superior recreational beaches. Water Resour. Manage., 20, p.151-159.

24. Wright, R.T., Coffin, R.B., Ersing, C.P., and Pearson, D. (1982) Field and laboratory measurements of bivalve filtration of natural marine bacterioplankton. Limnol. Oceanogr., 27(1), p.91-98.

25. Selegean, J.P.W., Kusserow, R., Patel, R., Heidtke, T.M., and Ram, J.L. (2001) Using zebra mussels to monitor Escherichia coli in environmental waters. J. Environ. Qual., 30, p.171179.

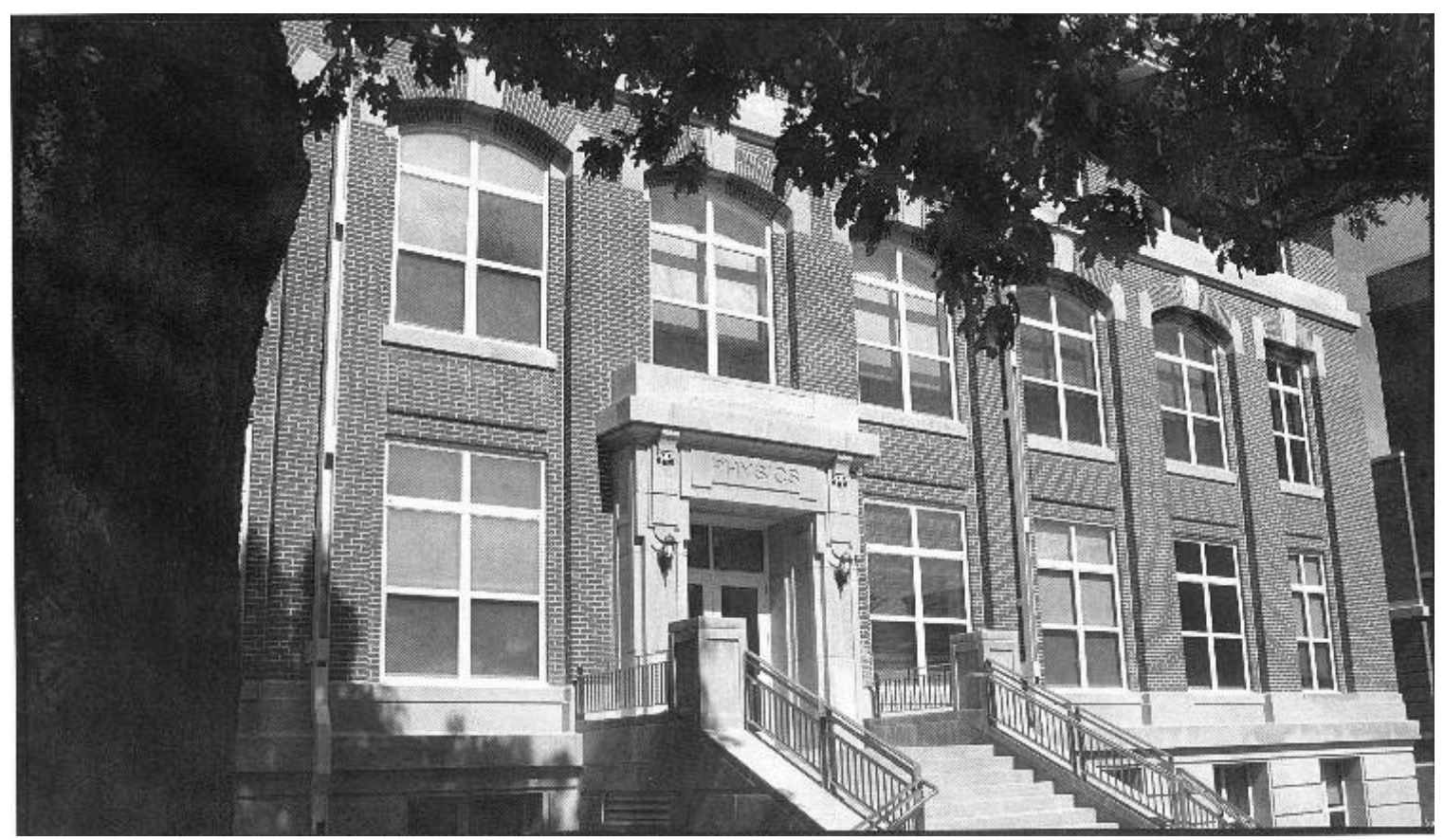

Begeman Hall - Department of Physics at the University of Northern lowa • Cedar Falls, lowa 50614-0150 USA • www.uni.edu/physics

\section{A national leader in physics education at both the undergraduate and master's levels.}




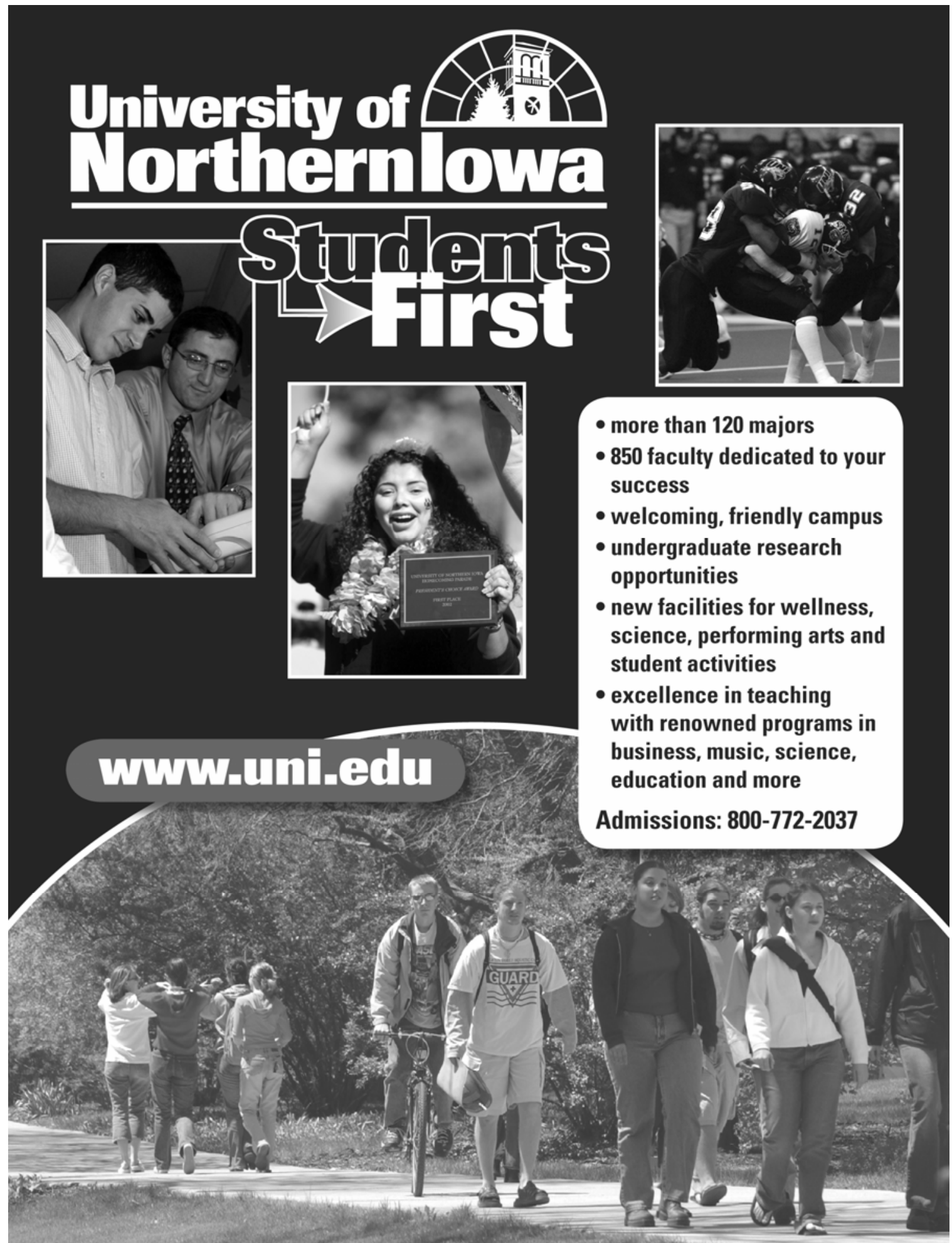

